\title{
PARKOUR, LEISURE AND NEOLIBERAL CITYSCAPES: A TWO-BOOK REVIEW
}

\author{
Parkour and the city: risk, masculinity, and meaning in a postmodern sport, by \\ Jeffrey L. Kidder, New Brunswick, NJ, Rutgers University Press, 2017, 256 pp., \$99.95 \\ (cloth); \$29.95 (paper).
}

Parkour, deviance and leisure in the late-capitalist city: an ethnography, By Thomas Raymen, Bingley, United Kingdom, Emerald Publishing Limited, 2019, 192 pp., $£$ 60 (hbk)

In the last decade or so the practice of parkour has been the focus of an increasing amount of interdisciplinary interest, especially amongst scholars addressing the global emergence and diffusion of lifestyle sports, and exploring the relationship between leisure practices and urban spaces. The two recent monographs addressed in this review meaningfully reflect this growing interest, and provide some relevant perspectives on current debates on parkour and leisure studies more in general. Furthermore, the review of these books also provides the opportunity to highlight current gaps and future developments in parkour literature, and the importance to address these for scholars addressing the relationship between leisure, forms of urban sociality and governance, and the political, economic and cultural realities of late-capitalism.

The first book, Jeffrey Kidder's 'Parkour and the city: Risk, masculinity and meaning in a postmodern sport' (2017) is an in-depth account of the meanings and practices related to the 'art of displacement' amongst members of the Chicago parkour community, and more widely amongst a number of traceurs in the United States. Drawing on 4 years of ethnographic research, the book sets out to provide a sociological and contextualised understanding of a practice that in the span of a couple of decades transformed from an obscure discipline practised in French urban peripheries to a global sport with mainstream appeal (p. 6). Some parts of the four chapters of the book represent a systematization of Kidder's previous journal publications on the topic, but the monograph nevertheless represents an original contribution and marking point for the literature on the subject. The book's first chapter provides an insightful and comprehensive historical overview of parkour from its informal origins to its global diffusion and contemporary institutionalization processes. In this chapter, Kidder identifies three 'business models' that marked the subsequent stages of parkour's diffusion as a mainstream cultural practice and product across the globe. This chapter offers an insightful historical and critical perspective to studies that have recently started to address the implications and tensions of parkour's institutionalisation in specific contexts across the globe.

Building on the first chapter, Kidder focuses the discussion of the second chapter on addressing the relationship between the globally inter-connected 'virtual' world of new media and the embodied and emplaced practice of parkour in local contexts. By engaging with Arjun Appadurai's concept of ethnoscapes (1996) Kidder draws on a series of ethnographic accounts to discuss how diffused and globalised representations of parkour provide traceurs with 'new prisms of the possible' that redefine what is believed to be physically possible and desirable through parkour 'offline'. In discussing how traceurs' knowledge around parkour is 'produced, altered and consumed online' (p. 49), Kidder then turns to Baudrillard's concept of simulacra (1981) to consider how traceurs' experiences of the practice could be irremediably shaped by the desire to produce images for mediated consumption. The consequence of this process being that the production of carefully crafted pseudo-events like edited photos and videos would take precedent over the actual event of parkour practice, reducing the experience of parkour manoeuvrers to mediated objects for consumptions. These points notwithstanding, Kidder 
convincingly draws on rich ethnographic descriptions to discuss how the meaning and purpose that the traceurs in the study found in parkour could not be reduced to the production of simulacra bouncing through cyberspaces, and thus argues that parkour's virtual existence is intertwined with, rather than determining, the discipline's material practices.

The latter enables Kidder to turn to traceurs' affective appropriations of urban spaces as 'manhood acts', and on their relationship with risk, the topics of the last two chapters of the book. Describing the embodied practices of parkour as 'urban adventure' Kidder discusses how the practising parkour represented opportunities for traceurs to bolster their masculine identities, while at the same time avoiding to be characterized as stereotypical jocks (p. 75). Kidder's discussion of the topic offers at the same time a welcome approach to the so-far almost inexistent (with some notable exceptions) discussion of gender in parkour, while also representing a relevant missed opportunity in this sense. Masculinity and gender scholars may be quite disappointed with the rather limited engagement with the scholarship on the topic in the analysis of traceurs' performances of masculinity, despite the central relevance of the theme in the book from the title. In particular, the discussion of traceurs' masculinities as 'not your typical jocks' could have been usefully elaborated through the lenses of inclusive, hybrid, and/or mosaic masculinities that have been recently used to address the construction of 'not your stereotypical jock' masculine identifications in a variety of physical cultures and contexts. Similarly, although partially explored in few instances of the book, the gendered meanings and practices of the females traceuses met in the research are seldom unpacked. Although doing this might have gone beyond the scope of the book's main focus on masculinity, it would have been a huge contribution to the field to discuss how the embodied and emplaced performances of masculine identifications were perceived, understood and negotiated by female traceuses. Finally, despite claiming that racial dynamics influencing the police, and other urban residents' responses to traceurs' 'urban adventures' is an unavoidable issue (p. 78), such issue is barely touched in the book. Apart from a comment on how 'it is not hard to imagine a much sterner response from the powers that be as traceurs gallivanted through the city [...] if Aero [the observed parkour community] comprised mainly young black or Latino men instead of clean cut white boys' (p. 79) the discussion of traceurs' manhood acts fails to acknowledge one fundamental issue: that it mainly related to the raced and classed performances of masculinity of 'clean, cut and mild-mannered white men' in a city that is 'infamous for its racial segregation' (p. 78;). This element reflects a widespread tendency amongst parkour researchers to adopt a normalised perspective that recognises traceurs as mainly male (and predominantly white, and middle class) and mostly young, thus skewing the gendered and racialized dynamics of contemporary cityscapes.

The last chapter of the book addresses traceurs' perceptions, practices and management of risk. Comparing Lyng and Snow's concept of edgework (1986), Kidder observes that while skydivers' engagement with life-threatening pushed the boundaries of survival through their actions, the traceurs' 'vocabulary of motives' to practice parkour was strongly grounded in narratives of progression and self-care. Through the concept of hedgework Kidder highlights how, despite public perceptions, traceurs' relationship with risk is generally inclined towards responsible risk-taking and 'hedging their bets'. Reckless practices and bragging about dangerous stunts are in fact generally reprimanded by the most authoritative and experienced traceurs in the community (p. 114). Kidder then proceeds to argue how the traceurs' ethos of self-care and risk-management meaningfully resonates with a pervasive ethos of individual risk-management and responsibility that characterizes the economic, political and cultural paradigm of neoliberalism. Kidder convincingly unpacks traceurs' hedgework through what he describes rites of risk and rituals of symbolic safety. Kidder's analysis of traceurs' relationship with risk, and its resonance with neoliberal moral imperatives of selfactualisation, responsibility and risk-management is compelling and meaningfully adds to similar perspectives advanced in relation to the diffusion of other lifestyle sports. What is surprising though is how the insightful discussion on the affinities between traceurs' practices and pervasive neoliberal moral imperatives does not extend to the way neoliberal policies that frame and shape traceurs' main 
playground, the city, and the traceurs' interactions with it. Again, given the centrality of the city in the study from the title, one could have imagined, or expected, a more detailed discussion of the main context of the study, Chicago. Instead, the spaces in which the traceurs train seem to represent a given background that, while meaningfully influencing what traceurs could afford to do in urban space, appear to be reduced to their materiality, as an a-historical and neutral scenario for the traceurs' 'urban adventures'. In this sense, the book's very final section entitled 'Reimagining the Neoliberal City' arguably lacks the richness and depth that characterized the rest of the book, and misses to provide some substantial discussion on the topic, exactly because previous parts of the book lacked to address the political economy of neoliberal Chicago, and how traceurs actually reimagined it. Despite this, and other shortcomings previously addressed, this text will deservingly represent a point of reference for under- and post-graduate students and leisure scholars who are interested in an accessible, grounded and compelling socio-cultural analysis of parkour as a lifestyle sport, and a global phenomenon.

Thomas Raymen's Parkour, deviance and leisure in the late-capitalist city is a fresh-from-print text that addresses the ambivalent relationship between the 'art of displacement' and the less-thancoherent manifestations of late-capitalism in the post-industrial cityscape of Newcastle-UponTyne. Based on an in-depth two years ethnographic study with young male traceurs belonging to the Newcastle's parkour scene, the book mainly applies an ultra-realist theoretical framework to reject 'the popular reading of parkour as a form of anarchic performative resistance against the late capitalist city' (sic!) (p. 9).

Raymen makes three interrelated arguments. First, rather than deviating from the ideological and cultural values of advanced-capitalist consumerism, the practice of parkour is currently constituted as a form of hyper-conformity to those very values. In other words, rather than a micro-form of resistance, parkour works 'hand-in-glove with capitalism's economic system by adhering to a fully commodified and culturally included logic of socio-cultural liberalism' (p. 18). Second, parkour embodies and reflects many of the changes relating to the nexus between leisure, work and identity in post-industrial societies. In particular, Raymen argues that parkour emblematically reflects the fact that the only basis which 'the late-capitalist subject' can construct a sense of identity is on the ever-shifting terrain of consumer, leisure and lifestyle trends (p. 22). Third, the 'paradox of parkour', as a culturally legitimate, but still spatially excluded urban practice illuminates the state of 'living-death' characterizing the city centres of post-industrial, 'creative' cityscapes in late-capitalism. In particular, the inconsistent exclusion and regulation of the practice from the cityscape makes visible the fragmented and privatized micro-spheres of spatial sovereignties that contribute to a significant ambiguity surrounding what is legitimate and illegitimate in the city.

In some of its parts this book represents a valuable contribution to a body of literature that has started to complicate parkour's early representations as subversive resistance to oppressive city space and as an activity untainted by commercialism. Chapter 4's discussion of the blurring between leisure and work related to the research participants' 'parkour lifestyle' effectively sheds new light on the figure of the 'entrepreneurial traceur' as productive consumer (or prosumer) ( $\mathrm{p}$. 80). This discussion convincingly illuminates the side-effects of the participants' immaterial labour as they attempted to make parkour an alternative form of livelihood to precarious and unfulfilling jobs in the service and retail sectors in post-industrial Newcastle, and offers a valid and critical development of the discussion on parkour ethnoscapes and simulacra advanced by Kidder. This chapter arguably sheds an important discussion on the work/leisure nexus that has not been yet addressed in relation to parkour and its ongoing 'sportization', and will appeal to critical leisure scholars more in general.

Similarly, Chapter 7, offers a novel perspective on the 'parkour city' by engaging with the perspectives of the almost archetypical 'arch-enemy' of every traceur: security guards. Through 12 walking interviews with security officers who were often tasked to move away the traceurs from their favourite spots in Newcastle, Raymen offers an original perspective that adds a rich counterpoint to the traceurs' practices discussed in the book. The chapter illuminates Newcastle's city- 
centre as a fragmented and paradoxic space marked by a multiplication of micro-sphere of sovereignty with competing interests (e.g. related to house-market value or the running of entertainment establishments) and in which parkour's spatial transgressions were more easily to be acted upon mainly because they were not legitimated by any economic stake on the spaces where they were enacted. The chapter's discussion meaningfully contributes to scholarly perspectives addressing the ever-tightening relationship between leisure spaces/practices and processes of market-driven urban rebranding, as well as the spatial and social consequences of these dynamics.

Unfortunately, the book's potentially novel and significant contributions to the literature on leisure, city-making and lifestyle sports are also consistently undermined by a series of omissions, problematic generalizations, and lack of accuracy surrounding the development of the book main arguments. One of the fundamental weaknesses of the book is its repeated claim to fill a gap left by a 'fetishistic attachment to the concept of resistance' (p. 7) in previous and current discussions on parkour. If this argument could have had some currency few years ago, a recent, but already quite substantial body of literature on the topic has provided meaningful discussions on the tensions inherent in parkour institutionalization and commodification, and its ambivalent positioning within neoliberal and post-industrial cityscapes. The engagement with this literature would have been hugely beneficial to shift the book's main points from the development of a somehow outdated polemic on parkour-as-resistance-or-cooptation, to a more structured contribution to our understanding of the work/leisure nexus as it applies to the ongoing 'sportization' of parkour and the political economy of regenerating, post-industrial and 'creative' cityscapes. As Stapleton and Terrio (2012) highlighted, parkour very existence as a global phenomenon stems from its appropriation and commodification by corporate marketers and elite tastemakers (p. 22). This analysis of parkour has been meaningfully developed by Kidder's (2017) discussion of the affinities between traceurs' 'vocabulary of motives' and a pervasive neoliberal ethos valuing individual responsibility and risk-management. Acknowledging these perspectives, the literature on parkour has nevertheless also shown how the discipline's ambivalence and capacity to cut across definitions of what is (il)legitimate and (un)desirable in contemporary cityscapes still represent a contested site from where to understand the daily reproduction and negotiation of 'creative' forms of neoliberal urban governance in specific urban contexts. The above mentioned discussions are unfortunately missed by Raymen's analysis. In spite of Raymen's admonishments to 'properly untangle and explain [parkour's] complex position at the nexus between spatially illegitimate deviance and legitimate commodified leisure' (p. 13), the book's analysis offers a bidimensional discussion of parkour as either a 'pure, non-commodified' and 'pro-social' practice, or (as Raymen argues) a discipline being eviscerated of its most positive aspects through its 'relentless commodification' (p. 150).

Unfortunately, while theorizing on traceurs' practices in Newcastle, Raymen also repeats Kidder's and other parkour scholars' lack of recognition of the gendered and racialized power dynamics in contemporary cityscapes. As the author admits in the book's very first page of introduction 'the traceurs were an entirely unthreatening lot' with 'innocent faces and fashionable floppy hairstyles' (p. 1), and one traceur even acknowledges the fact that being young, white, educated 'kids' (p. 113) helped in making their relationship with security officers relatively problem-free (a perspective that is reciprocated by the security guards in chapter 7). Once again, the lack of discussion of the specific affordances that the traceurs' gendered, raced and classed bodies provided them as they navigated Newcastle's cityscape while practising parkour contributed to oversee the existence of other meanings, stakes, implications and experiences of movements and place that can be experienced, negotiated and made visible in urban spaces through this discipline. This oversight is even more relevant as Raymen recurrently draws on the participants' experiences and vicissitudes to make a number of sweeping considerations on the condition of the 'late-capitalist subject'. In these theoretical considerations on the relationship between the 'late-capitalist subject', leisure, work and neoliberal city-making, the gendered, classed and racial specificities of the traceurs in the study is consistently disavowed, thus leading to 
a number of essentialised claims that manage to undermine the in-depth and contextualised descriptions of the participants' practices in other parts of the book. I would contend that Raymen's book is much more convincing when its rich ethnographic data are given more space to convey the experiences, vicissitudes and emblematic contradictions of the young traceurs' practices in the study, while it is only partially successful in achieving its main aims due to the above mentioned shortcomings. Post-graduate students and leisure scholars might still find relevant insights in the book discussion of parkour and prosumption (Chapter 4) and in reading the security officers' perspectives on parkour (Chapter 7).

\section{Disclosure statement}

No potential conflict of interest was reported by the author.

\section{References}

Appadurai, A. (1996). Modernity at large: cultural dimensions of globalization. Minneapolis: University of Minnesota Press.

Baudrillard, J. (1981). Simulacra and Simulation. (S. F. Glaser Trans.). Ann Arbor: University of Michigan Press.

Lyng, S., \& Snow, D. (1986). Vocabularies of motive and high-risk behaviour: The case of skydiving. Advances of Group Processes, 3, 157-179.

Stapleton, S., \& Terrio, S. (2012). Le Parkour: Urban street culture and the commodization of male youth expression. International Migration, 50, 18-27.

Nicola De Martini Ugolotti

Department of Sport and Physical Activity, Bournemouth University D http://orcid.org/0000-0001-5149-7617

(C) 2019 Nicola De Martini Ugolotti https://doi.org/10.1080/02614367.2019.1604792 